\title{
AN INNOVATIVE MODEL FOR ECOTOURISM ATTRACTION ON DESTINATION BRANDING IN MARINE NATIONAL PARK AREA OF KRABI PROVINCE, THAILAND
}

\author{
THANAWITPIANDEE ${ }^{1 *}$, DR. THIRACHAYACHAIGASEM ${ }^{2}$, DR. PHITAKSIRIWONG ${ }^{3}$ \\ \& DR. SOMRUTHAISOONTAYATRON ${ }^{4}$ \\ ${ }^{1}$ Student of Tourism and Hospitality Innovation Management Department, Faculty of Business Administration and \\ Accountancy.KhonKaen University, Thailand \\ ${ }^{2}$ Assistant Professor, Head of Ph.D Program in Tourism MICE and Hospitality Innovation Management, Faculty of Business \\ Administration and Accountancy KhonKaen University, Thailand \\ ${ }^{3}$ Associate Professor, Vice President for Social Enterprise Development, Silpakorn University, Thailand \\ ${ }^{4}$ Faculty of Sports Science, Chulalongkorn University, Thailand
}

\begin{abstract}
This article aims is to create an innovative model for ecotourism attraction on branding destination in marine national park area of Krabi province. This research is using Structural Equation Modeling (SEM) by M-PLUS program to develop a model of the factors influencing ecotourism and destination branding. The data were collected from 400 samples from tourists visiting marine national park area of Krabi Province. This study formulated a final structural model according to the tourist opinions from Krabi Province, Thailand, as element of tourism behavior in marine national park area of Krabi province consisted of the following 5factors: 1) Information perception factor. 2) Cultural factors. 3) Social factors 4) Psychological factors and 5) Marketing factors. Elements of branding destination of marine national park area of Krabi province consisted of the following 9 factors:1) Branding Destination Meaning 2) Branding Destination Identity3) Branding Destination Personality4) Branding Destination Image5) Branding Destination Equity6) Perceive Branding Destination Value7) Branding Destination Commitment and Attraction8) Branding Destination Logos and 9) Branding Destination Tourism Character. Elements of ecotourism management of marine national park area of Krabi province consisted of the following 4 factors:1)Area 2) Management 3) Activities and processes and 4) Participation.

KEYWORDS: Innovative Model, Ecotourism, Destination Branding, Marine National Park, Krabi Province \& Thailand
\end{abstract}

Received: Jun 08, 2020; Accepted: Jun 28, 2020; Published: Sep 05, 2020; Paper Id.: IJMPERDJUN20201081

\section{INTRODUCTION}

The situations and trends of Thai tourism industry is still growing continuously. Thailand has still potentials and opportunities for tourism development, such as being located in the center of Southeast Asia, having diversity of natural resources, art, and culture, as well as Thais friendly behave. In 2017, the Global Tourist Destination Index survey by Master Card gave Bangkok as the most popular tourist destination in the world which has been popular for two selected years from all 135 countries around the world.In addition, Thailand also got the best travel country award in family tourism, leisure tourism, and the tourist attractions for weddings. All of these awards was resulted from the cultural identity and variety of tourist attractions that showed the potential and capabilities of Thailand as the world - class tourist destination in the tourism industry.(National Tourism Policy Committee, 2015) 
The creation of destination branding is an important concept in the development of tourist destinations in Thailand. Increasing the efficiency of marketing communication through various tourist brand brands and tourism brand products are the heart of modern marketing. Through the concept of stamping symbols and special experiences, it will create familiarity and bond between the brand, tourist attraction and the mind of tourists. However, the marketing of tourism branding in Thailand is nowadays not as clear as it should be. With the unclear of that, it is needed to improve so that Thai tourism brand is clearer than it is today.In this regard, there are many ways to create a brand in Thailand whether it is brand positioning, in order to communicate to the target consumer group and look at tourism in Thailand that is meaningfully different from other countries that are competitors. Tourist attractions that can be used to create a brand will help the brand to be realistic and to be able to maintain the identity of tourism by having the brand image that can be recognized by tourists.

Krabi province is a province that has potential for national and international tourism. This province has been supported from government sector to encourage Krabi province to be a source of income from tourism that has continuously increased. Taking into account the capacity of the area by promoting and supporting all sectors involved to create added value for the tourism service chain is considered under many reasons including to create tourism with an emphasis on quality and eco-friendly, to develop of marine tourism business with cruise ships, to develop of a basic service system and adequate quality facilities, to have a security system that meets international standards in order to support new groups of tourists, to make the southern region as travel target of travelers traveling by cruise ships, and to promote as well as develop tourism links between tourist sites in international level in the southern Andaman coast, the Gulf of Thai, tourist attractions in the south of Thailand, and other potential tourism sites to be a travel network route. Also, the linkage between the new tourist attractions and famous tourist sites within the province is included (Office of the National Economic and Social Development Board, 2017).

In addition, Krabi is perceived as the world-famous pelagic attractions which is located and took care by the National Park Office, Department of National Parks, Wildlife and Plant Conservation. There are tourist attractions in the province including Noppharatthara Beach-Pee Pee Islands National Park, Mu Koh Lanta National Park, and ThanbokKhoranee National Park. All of the 3 parks are located in the sea area of Krabi province. Each place is an interesting tourist attraction which can attract tourists to travel through the image of a world-class tourist attraction (Office of Department of National Parks, Wildlife and Plant Conservation, 2016). Based on the results of the study about the situation and the opportunities to promote the tourism market in the group of Eco and Adventure studied by the Tourism Authority of Thailand, it found that Krabi province is one of the marine ecotourism provinces where the area is full of natural resources and is equipped with activities. The strengths that should be promoted in marketing is the integrity of the world-famous sea, and mangrove forests.

Beside on the measurement closed in order to the bay and limit the number of tourists, Krabi province also has guidelines for provincial development in accordance with the Krabi province strategic plan for sustainable conservation and restoration of natural resources and the environment. "Policy of Krabi Go Green" focuses on the nature and safety tourism. Latest, NopparatThara National Park, Phi Phi Islands, Krabi has intensely controlled the restriction rules to prohibit tourists from bringing foam boxes to various tourist attractions in the park area and requesting cooperation to not use hard-degradable plastic bags in order to reduce the impact on the environment and protect the wetland of the Krabi estuary. Krabi is thus a paradise of ecotourism that is completely beautiful and pollution-free. 
For these reasons, it is concluded that the researcher is interested in and choosing the tourist attraction of Krabi province as the research area. The researcher has the intention and consideration of the importance of creating a brand of tourist attractions in Krabi province to be internationally recognized. Focusing on marine tourism, which is under the supervision of the National Park Office, can raise the level of ecotourism attraction on branding destination in the three marine national parks of Krabi province. With the reputation of three marine national parks, it can lead to branding destination by applying creativity and tourism innovation to be ecotourism branding destination to provide value and experience to tourists. By focusing on quality tourists to be in the line with tourism activities, tourism activities are worth in the experience rather than the value of money. With this approach, it will create more value for tourism and aim to be a tourist attraction that both foreign tourists and Thai tourists will always think of. For traveling, the tourists will choose the places at first priority. This will drive the tourism to be sustainable in the way of economic, social, cultural, environmental, and community participation.

\section{LITERATURE REVIEW}

\section{Tourists Behavior}

William D. Perreault,Donna K. Darden \&William R. Darden (2018) proposed 4 tourist behavior patterns:

- Budget Travelers: In general, this type of traveler is a middle-income tourist, but seeking a vacation or a low-cost tourist.

- Adventurous Travelers: It is a well-educated traveler with moderate to high income, and has a passion for activities during vacation or adventure travel.

- Vacationers Travelers: A small group of tourists who often take time to think about travel or travel the next time they go, however, this group of tourists is quite enthusiastic but earns quite a bit.

- Moderates Travelers: Travelers who are passionate about travel, but do not care about travel during weekends or spending time with sports, but prefer longer trips.

Cohen (1979) proposed the following behavior patterns for tourists:

- Recreational Tourists are tourists who emphasize the importance of activities related to recreation or physical rest.

- The Diversionary Tourists are tourists who try to find ways to forget the monotony of everyday life.

- The Experiential Tourists are tourists who travel to seek real experiences. This type of tourist is interested in studying and getting the real experience of a tourist attraction that has been touched. For example, when traveling to Spain, they want to experience the way of life of the local people or the true culture that belonged to Spain.

- The Experimental Tourists have a distinct characteristic that is like contacting and talking with local people to learn and understand life and adapt to the environment of local people.

- The Existential Tourists: These tourists want to bury themselves or live under the same culture and way of life as the local people. This type of traveler will spend a lot of time in the tourist destination for a long time. For example, tourists who come to spend time in some tourist destinations in Thailand, such as Pattaya or Chiang Mai, and try to live the same life as local people, whether it is self-practice, eating, and trying to speak local language etc. 
Swarbrook and Horner (2007) proposed the following tourist behavior:

- $\quad$ Active Sea Lovers

- Contact-Minded Holiday Makers have a passion for meeting other people and seeking new friends that are local people.

- $\quad$ Nature Viewers like the beauty of the landscape of tourist attractions.

- $\quad$ Rest-Seekers spend more time sleeping and resting than other activities.

- Discovers like activities, adventures, and likes to find new friends.

- Family-Orientated is a tourist who is passionate about the sun and sea and likes to travel as a family.

- Traditionalists like to travel that emphasizes safety and not risk.

From reviewing the above documents, it can be concluded that the perception and behavior of tourists must be studied in the theory of perception, motivation, learning, beliefs and personality attitudes, patterns of living, and ideas about yourself. By the theory, it can analyze the behavior of tourists in terms of process, behavior of tourists, the role of tourist behavior, and determining tourist behavior patterns.

\section{Destination Branding for Tourist Attractions}

In this section, the literature review is divided as follows.

\section{Concept of Branding Destination Meaning}

Apisit, C. and Lakkhana, L. (2005) said that the brand image or popularly known as the brand (Brand). The Marketing Association of the United States has defined the meaning of the name, word, symbol, style, or a combination of such things as intended to represent the product or service of a seller or group that makes a difference from the competitors under trademark law. Sellers have the right to use the "branding" that can be created at all times, which is different from patents or copyrights that have an expiration period. Good brands must be unique and difficult to imitate from competitors, thus creating a sustainable competitive advantage for that product or service.

Jirasek, T. and Apisit, C. (2007) stated that the brand can make the product different in the mind of the customer. For example, generally speaking, orange is orange, but if it is a branded orange and there are over 80 percent of consumers know that product name and trust will be different from the general orange, etc. Therefore, a strong and well-known brand can sell products at a high price, but at the same time these organizations need to invest in brand building for a long time, especially advertising, promotion, and Product model development and packaging.

Upendra, K. M., (2012). said that a strong brand is something that tells consumers about the quality of products or services and that those who regularly buy products are confident that they will receive the product with the same appearance, benefits and quality every time. The brand became the basis for creating a story about the unique quality of that product. InterBrand has estimated the value of the brand, which will change over time each year. Therefore, the brand management must be professional, able to create, maintain, protect and upgrade the brand or service that is responsible.

\section{Concept of Branding Destination Identity}

Brand identity clearly specifies what the brand aspires to stand for and has multiple roles. First, it is a set of associations 
that the brand strategist seeks to create and maintain. Second, it represents a vision of how a particular brand should be perceived by its target audience (Aaker \&Joachimsthaler, 2000). Third, upon its projection the brand identity should help establish a relationship between a particular brand and its clientele by generating a value proposition potentially either involving benefits or providing credibility, which endorses the brand in question.

The role of identity as a supply-side concept involving the decision-making powers of business owners and tourism managers is underpinned by previous definitions (Kapferer, J. N. 2008). Further, some definitions (Aaker \& Joachimsthaler 2000) identify the role of identity has having a dual purpose in analysing brands from the inside on one hand, and on the other to subsequently calculate the brand equity which involves the accumulated sum of the value consumers attach to particular brands, as well as their confidence in and loyalty to a brand (Arnould, Price \&Zinkhan 2002).

The multiple roles of the brand identity concept are reflected in investigations. For example, Kapferer, J. N. (2008) a hexagonal model called the brand identity prism. It is based on six central components: physique, personality, culture, relationship, reflection or image and self-image. Later, Maja Konecnik.R. and Leslie De C. (2013).adapted Kapferer's brand identity prism. The former conceptualises brand identity in terms of its vision and culture which, in turn, drive its desired positioning, personality and subsequent relationships, all of which are later presented to reflect the stakeholders' actual and aspirational self-images. In our opinion, Aaker, David A. and Joachimsthaler E. (2000) said brand leadership model is so far the most comprehensive in the literature for three reasons. First, the model is systematic. Branding can easily become overwhelming in the multitude of components and theories that play a role in brand identity development. Therefore, there is a need to provide guidelines enabling decision-makers to examine issues utilising a threephased structure: a pre-analysis of strategic processes;

Tourism destination brand identity system analysis; and a post-brand implementation process. Second, the model is comprehensive, i.e., its brand leadership model underscores the subject in its breadth. The model covers both the strategic and visionary roles of managers rather than limiting the discussion to their tactical and reactive roles. It focuses on the issue of strategic brand control, i.e., setting out what a brand should stand for from the perspective of relevant stakeholders, including customers and subsequently communicating the desired corporate identity consistently, efficiently and effectively. Third, the model is pragmatic because it recognises that decision-makers should be involved in both formulating and implementing the business strategy. Both the strategic vision of the decision-makers and their corporate culture should have a significant influence on the destination's brand strategy. In practical terms, it implies that a destination brand identity strategy should not promise what a destination cannot or will not deliver (Aaker, David A. and Joachimsthaler E., 2000). While both theAaker, David A. and Joachimsthaler E., (2000) versus Maja Konecnik. R. and Leslie De C. (2013)are the most relevant, we feel that the former's comprehensive nature currently best suits the peculiar notion of the tourism destination brand context.

\section{Concept of Branding Destination Personality}

Brand personality is a part of the Brand Image which includes all attributes of an intangible product. This is defined in its most recent wording as: 'The set of human personality traits that are both applicable to and relevant for brands'. (Azoulay\&Kapferer, 2003) 
Aaker (1997) conducted the foundational study which applied the concept of brand personality to tourism contexts, which is now a commonly accepted belief that tourist destinations can have personalities and be marketed as brands. Specific to destinations, brand personality can also be associated with the set of unique and favorable associations and memories that tourists have connected to a particular place. Since then, several studies have investigated the role of destination personality in evaluating scale development and tourists' behavioral intentions.

Ekinci and Hosany (2006) found dimensions of sincerity, excitement, and conviviality. Soyeon Kim and Xinran Y. Lehto(2013)found seven dimensions: excitement, competence, sincerity, sophistication, ruggedness, uniqueness, and family orientation. Hultman, et al. (2015) found six dimensions: excitement, sophistication.

Blain, et al., (2005) argues that destination branding is like a marketing sum that helps support creativity in presenting features of tourist sites, whether it's the name, symbol, symbol, slogan or image created to display the difference of tourist attractions in various countries. In addition, tourism brands also emphasize and remember the past or upcoming travel experiences. It also helps increase the potential for participation or linking the feelings of tourists and tourist attractions together as well as helping to reduce awareness about the crisis or expenses that arise from tourism as well. Therefore, the concept of the brand has become an interesting issue in today's tourism education with the concept of branding linked to tourism promotion in various countries.

Bui (2010) proposed in his research about the Guam Island brand and the Vietnamese brand that tourism brands were used as a tool to build the country's potential, not only using natural attractions but also creating differentiation through branding strategies in each group of tourists. Being a travel brand consists of a number of factors that are related to each other, such as location and demographics: Location includes physical characteristics, tourism patterns, natural resources, local products, and demographics includes race, people, history, culture, language, economy, political system, social institutions, utilities, people's well-being, and image (Olimpia, B. 2008). It can be concluded that the value of the tourism brand in the country is influenced by the image and personality of the country, where the brand value of the country is considered an important asset or capital for building the competitiveness of the country's tourism. Tourism brands will help generate income and economic competitiveness for the country as well.

\section{Concept of Branding Destination Image Including Cognitive Image, Unique Image,}

\section{Affective Image, and Overall Image}

Elements for the image of the place, Echtner and Ritchie (2003) said that measuring the image of the place consists of 3 directions:

- Functional Characteristics -Psychological Characteristics

- Attributes -Holistic

- Common - Unique

Direction 1: Functional image - Psychological image: Functional image that will be the image that is evaluated from the physical characteristics of places such as mountains, sea, parks, shelters, entertainment, shopping, historical sites, museums, climate, and tourism facilities. The psychological image will be the image that affects feelings such as relaxation, safety, increasing knowledge, and the friendliness of the local people. 
Direction 2: Images based on details (Attributes) - Overall image (Holistic) is a direction that involves measuring the image by detailing and overall image measurement. Measuring the image of the place is based on various details, such as the beauty of the sea, the prosperity of the city, the availability of various entertainment sources, the safety of the country, and the quality of facilities etc. The overall image of the place will be a measure of the image of the place of the province or the country as a whole, such as the overall image of the country or the feeling of the atmosphere in the place.

Direction 3: Common image - Unique image. Measuring the image of a place can be measured from the general characteristics of a particular place or country, including the functional image and the psychological image, such as the beauty of the place, transportation facilities, entertainment, relaxation culture, and safety of a country, etc. Also, measuring the image of a place can measure only the characteristics that are the hallmarks of each place or feature of each country, such as Taj Mahal in India or Mount Everest in Nepal. Echtner and Ritchie (1991) studied the image of Nepal by collecting details of the image in various forms of Nepal. They can identify various images according to the direction used to measure the image of location and image of the psychology.

In addition, Beerli and Martiín (2004) have collected literature relating to the image of places from many researchers and have categorized the elements of the image into 9 elements, namely, natural resources, general structure, structure tourism, recreation, arts and culture / history, economy and politics, natural environment, social environment, and the atmosphere of the place. Destination Image study found that the formation of the image has factors that are visible or known as Tangible Attributes and psychological factors or intangible feelings such as fun, impression in culture (Intangible Attributes).

\section{Concept of Branding Destination Equity}

Pradit, C. (2004) stated that the brand value and brand equity value are similar. Brand value refers to the true financial value of the brand, while the overall value in the brand means both the name of the brand, the symbol, the consumer's imagination about the product, and the relevance and perception of consumers who are represented in the form of abstracts and concepts that cannot be captured by the brand that consumers create. The overall value of the brand has a variety of dimensions that are different from the brand value. Having a high value in the brand will make it possible to set a high selling price (because consumers are willing to pay more when compared to other brands). Also, having a high value in the brand will make benefits for customers in various ways: Customers are satisfied and loyal (the level of brand satisfaction will help consumers become loyal and prevent price sensitivity). Customers are aware of the quality (consumers acknowledge the higher quality of the product compared to competitors). Customers are aware of the value of the product (consumers understand the value of the product received, not only the value of money or quality but also other values that can't be caught as well). Customers have a heart-to-heart relationship with the product (consumers have a mental relationship with trust in that product). The customer has a unique personality of the brand (which the characteristics of this brand make it different from the competition). Customers have awareness and recognition of the brand (It is important to measure how successful the brand is, how strong it is measured by the brand's familiarity in the market). The overall value of this brand will be held together by what is called "Essence of the brand".

Upendra, K. M,. (2012). stated that the brand equity value means the brand of products that consumers perceive as valuable as a brand that consumers have a positive attitude towards the product's characteristics and that of the brand. Creating branding for value is as follows. Create an appreciation of the quality of the product (appreciation of quality) means that consumers recognize the quality of all products or services and then impress the product or service. Creating an 
impression (appreciation) is different from creating satisfaction. Consumers are aware of the added value that can be delivered.

- Causing customers to buy products (Reason-to-Buy)

- Making the product have a stable market position (Strong Position)

- High level products (A Price Premium)

- Channel distribution (Channel Member Interest)

- Making it possible to expand the product line (Brand Extension)

\section{Theories of Perceive Branding Destination Value}

Research on the perceived value of Thailand of 540 UK tourists at Bangkok International Airport (Don Mueang) was processed by using a questionnaire consisting of 3 sections: (1) general tourist information, (2) tourism value, and (3) opinion general. The author tested the questionnaire and tested the reliability of the questionnaire which obtained the overall value (Cronbach alpha) equal to 0.89 and used statistical tools such as Factor Analysis, Multiple Regression and Two-group MANOVA.

The results confirm that Thailand, as a tourist attraction, has a value that can be delivered to UK tourists as detailed below.

- UK tourists recognize tourism values in many dimensions, which can support the value theory of customers in many areas, including economics (Thaler, R.,1985), psychology (Reynolds, T. J., \&Gutman, J. (1988)and social aspects (Schwartz, 1994). In addition, it shows that the tourism experience consists of (1) the quality of service in the form of attributes (attribute-based), and (2) the quality of the holistic-based experience which results in each other. It can be explained according to Gestalt theory. The Gestalt theory suggests that outstanding features may substitute for inferior features, as can be seen that customers are overall satisfied even if they are not satisfied in some way. In this research, four respondents were stealing things during travel, but also evaluating overall satisfaction in the moderate to highest level of tourism in Thailand.

- Monetary value (utilitarian-based): UK tourists have experience traveling in Thailand and see that it is worth the money. It showed that this value was the most outstanding value in Thailand which results in high satisfaction for tourists, wanting to travel back again, and telling people around you to know the value of Thailand.

- Emotional value (Experience-based): Emotional values are important indicators for tourists' satisfaction and repeat travel that is consistent with the concept of quality of experience (Otto and Ritchie, 1996). Tourists evaluate the overall travel experience (holistic) from internal feelings (self) and external environment. In addition, according to the study of emotions (Russell, 2003) found that emotions can be divided into two conditions: activation - deactivation, and pleasure - displeasure.

The emotion that expresses excitement and excitement (pleasant feelings) will result in more satisfaction than a relaxed mood, together with pleasure (pleasant feelings). This means that UK tourists see the emotional value of excitement rather than relaxation, in line with the concept of Botterill (1987) that the events that tourists have never expected before will affect overall satisfaction. 
- Functional value - attribute based: Although functional value, which consists of tourist sites and tourism infrastructure, is a value that can affect overall tourist satisfaction, but in this research, it is found that the essence of Thailand cannot be making the UK tourists want to travel again and be the weakest value in all four dimensions.

- Interpersonal Value-Process-based: It was found that the relationship between people in the service process of Thai people did not significantly affect overall tourist satisfaction. Although this value does not affect overall satisfaction, it is found to affect the intention to travel to Thailand again. This is a new knowledge of tourism research. United Kingdom tourists are extremely satisfied with the hospitality of Thai people and are impressed with the sincere smile of Thai service providers. However, they see that the quality of service is still poor, and smiles cannot help travelers see better quality of service. That is consistent with research of "Duchenne Smile" (Grandey et al., 2005), which found that a sincere smile can help increase satisfaction when receiving good services.

- There is a difference between UK tourists traveling to Thailand for the first time and repeat travelers. Travelers traveling for the first time have the motivation to seek challenges (challenge / knowledge), socializing and honor (social / prestige) more than tourists who have already traveled. however, these two groups of tourists have the same motivation as wanting to relax, which coincides with the concept of Cohen (1972) that travelers traveling for the first time are in the category of explorers who like to live in an environment that is familiar with Exotic, while tourists who travel to Thailand repeatedly belong to the category of tourists who like to live in the familiar environment (The Individual Mass Tourist). Travelers who travel repeatedly also like and appreciate the value of Thailand more than tourists who travel in the first time. There are three values of Thailand, including Interpersonal values, relaxing - pleasant feelings, and emotional value in tourism infrastructure. It can be interpreted that tourists who travel to Thailand repeatedly because of the hospitality of Thai people when they have been in Thailand. They feel the atmosphere that will come to relax and be happy, satisfied with the Thai tourist attractions, accommodation and other utilities more than the first travel group

\section{Concept of Branding Destination Commitment and Attractant}

Kotler, P., \& Keller, K. L. (2012).classifies the market level into traditional markets in order to create brand awareness that previously focused on 4Ps, which includes products, prices, place, and promotion. A market that focuses on providing a good and impressive experience for customers, called "Experiential Marketing". If tourism is able to create an experience of using products or services that are good for the target customers, it will lead to creating a strong emotional bond with consumers - such as Starbucks coffee shops that are marketed by using the concept of five-touch marketing that uses sensory transmission to create impressive experiences to customers, including images, flavors, smells, sounds, and touches.

Moreover, Lidia Andrades, L., Dimanche, F. and Ilkevich, S. (2015) said that the experience of leisure and tourism is atthe level of the consumer's feelings. Focusing on providing experience to tourists is to create awareness, feelings, behavior, and value for tourists based on knowledge and understanding of tourism products / services. The tourism experience has three main components: Functional experiences is the satisfaction that tourists have for their services or tourism, taking into account the value of money, such as quality, price, service of guides and tour services etc. Social experiences are values that tourists receive and contribute to making benefits for society, such as environmental conservation and social assistance etc. Emotion experiences is the feeling and value that tourists get when choosing to do 
travel activities and feel that they are different from other places that have ever been. The study of travel experiences is necessary to combine both the experience of leisure and travel activities, as tourists have an expectation of collective experience from both sides. Creating a good experience for tourists must focus on the quality of services, both tourism and recreation.

\section{Concept of Branding Destination Logos}

Nowadays, the company logo is a very important thing, whether it is a product logo or company logo, because the logo will help the business to progress and succeed. Making logos requires a lot of creativity and imagination, so the logo is unique and unique. The goal of most logos is to create a brand for products or services. Therefore, the logo design is the most important to create a brand that is outstanding and interesting, and also helps to promote the business to grow. In order to start any business, whether for commercial purposes in companies and organizations, you must first understand what the logo is, and what it is used. The logo is not just a sign, but the logo reflects the image of the business of your business through shapes, letters, colors, or images. So what is the logo used for?

- Psychology is to require consumers to feel, feel confident, understand the product and accept the product, and most importantly, to create the impression of consumers.

- Behavior is the need for consumers to show behavior that responds to the corporate identity.

- In terms of image, it is important for the consumer to have a positive attitude and popularity with the manufacturer.

\section{Logo Design}

- Meaning of symbols or logos

The symbol or logo comes from the full word of "Logotype" that refers to either a symbol, a sign, an agent, or a representative that indicates the type, style, or description of what is owned by that symbol or logo.

Logo is a symbol that represents images, symbols and marks, including products and manufacturers. The design of the logo, product and company makes it unique and unique, which helps to be reliable and free to consumers. Therefore, the logo can inspire, belief, popularity and recognition about the organization or product. It is the work of a designer to create a logo for such purposes because the logo is not just a sign, but the logo reflects the image of the business market.

Logo is a symbol or symbol that is a result of graphic design related to symbols (Symbolism). It is an image, symbol, or mark that helps create identity for their products and companies. The main objective is to have a unique identity of their own in accordance with the product and to allow the visitor to see easily, reliably, or imprint the consumer forever.

- The importance of logo design

Nowadays, logo design should take time to think and analyze various information so that the logo that is designed meets the company, product, or service, which can accurately reflect the desired image to the outside as expected. Therefore, the importance of logo design is as follows:

- Logo design helps to present with a simple graphic symbol or image as a symbol of a company, organization, or store, but it is important to have the power to attract and display the image of that product, such as men's products - the logo should convey strength, strongest, or smartness. 
- A good logo design will help people or target customers to recognize as soon as they see and can inspire, create brand loyalty, acceptance and appreciation. A good logo is the basis of the concept or value of a perfect company.

- The most important logo design is to impress the viewer, which must be meaningful and easily recognizable as a symbol that can enter into the mind of the customers. The logo design must be unique and do not affect the change of time. In addition, it must be flexible in terms of size because it must be used in places such as large billboards. One of the important elements is clarity and easy to see.

- Logo design is a rather complex process, as if defining the identity of the business. In addition, the logo design must suit or match the preferences and values of the customer, indicating the value of the company that must be carefully understood and clear as well as able to compete with competitors.

- Logo design and brand building is a combination of two factors: quality and sight. In this globalized world, it is an indication of the intelligence of a company that will be able to survive at all times from competition.

\section{Theories of Branding Destination Tourism Character using PECT Analysis Including economic,}

\section{Culture and Social, Politic, Technology, and Environment}

\section{Tourism Character}

PECT analysis is an important tool and is used for analysis in a broad overview from the creation of all travel destination brands as to how it affects. Branding factors for travel destinations consist of all 5 factors: political, economic, social and cultural factors, technology, and environment (Kim, W. H. et al. (2018).

\section{Politics}

Politics is an analysis of policy and political factors that are constantly changing. The government may issue certain policies that have both positive and negative impacts on the tourism industry. Therefore, the analysis of this factor depends mainly on political conditions. For example, politics has pushed for reform which has resulted in political instability which will cause various businesses to accept events. There are various factors as follows.

- The status of security and the form of government that has changed.

- There are many corruption issues in the country so that the taxes of thepeople are not being promoted in other utilities.

- Freedom of doing business in various forms of each locality.

- $\quad$ Rules, regulations, and prohibitions for doing business.

- Import and export control.

- How to collect fees and collecting taxes.

- Laws in various areas such as environment, piracy, visa cancellation, andfees.

- $\quad$ Tourism promotion policy.

\section{Economics}

Economics is an analysis of the environmental factors of both domestic and international economies and the world 
economy. The global economy is another important factor that directly affects tourism and affects the travel of tourists around the world. For example, an import-export business must be interested in fluctuating exchange rates that will result in profit or loss in exchange rates. Interest rates are another important factor. If the interest rate increases, it shows a better economic condition. At the same time, it will affect the financial cost of the company as well. Factors affecting the economy are as follows.

- Deflation, inflation, and interest rates

- Exchange rates in the country

- Unemployment rate of people in the country

- Minimum wage rate and average wages for employees

- Class and purchasing power of people in the country

- The price ceiling of the products and services that we are interested in.

- $\quad$ Stock market of the country

- The cycle of tourism and related businesses in the tourism industry

\section{Culture and Social}

Culture and social is an analysis of social factors, whether it is a cultural environment in which each nation is not the same. For example, current tourist behavior trends - of the elderly society, individual behavior, cultural background, lifestyleare important trends in the behavior of tourists or people around the world.

- How much is the increase or reduction of the population insociety?

- Attitudes towards preserving the environment of people in the community.

- Spending of people in the community, focusing on imported products or local products in the area.

- How much news and information are effective?

- Other behaviors such as health care, convenience from traveling in the community, etc.

- Lifestyle of people in society

- Behavior of buying products

- Immigration rate in or out of people in the community

- Quality of life

- Age and gender

- Classification of castes

- Rights and freedom of people 


\section{Technology}

This factor is considered a very fast change. It can be seen that technology has evolved, affecting all sectors of businesses that need to use appropriate technology to reduce costs or increase competitiveness. For example, the use of technology in the areas of assistance in managing travel of tourists, the use of travel technology, tourism information, virtual tourism, and the use of technology for travel choice travel.

- Basic technology of that area

- Technology change rate

- Quantity of builders and developers

- The level of technology of the industry in the community

- Communication technology

- Access to new technologies

\section{Environment}

Environmental factors are one of the important factors for tourism analysis. Because tourism is an activity that uses natural resources primarily and has demand-supply according to the tourism season, it therefore should focus on environmental factors in analyzing factors that affect by natural factors such as drought, global warming, or flooding.

- Are the terrain vulnerable to natural disasters?

- History of natural disasters in areas such as floods every year Tsunami, earthquake, strong winds, mudslides, and volcanoes.

- How far has the climate changed?

- global warming

- Natural and environmental conservation plans for tourist attractions such as marine tourism, park tourism, and ecotourism

\section{Ecotourism}

Ecotourism is the result of three main demands (Helen Perkins,. H. and Debra Ann Grace, A. D., 2009).

- The need of the world to create a conscience to conserve the environment in tourist sites, especially ecological conservation to maintain biodiversity.

- Increasing demand for tourists who want to learn more in tourist attractions.

- The need for local communities to participate in tourism development. From such demands, it has caused the awareness of tourism development to be a new alternative. Ecotourism has been mentioned most since ecotourism has four basic concepts:

- The use of sustainable tourism resources without creating a negative impact on the environment because the environment is an important tourism resource and is an eco-tourist attraction. 
- Being able to create consciousness in preserving the environment and tourism resources to help attract tourists, therefore it is necessary to conserve.

- Creating satisfaction for tourists because eco-tourists will be satisfied with learning and seeking experience from tourism.

- To allow local communities to participate in communities that are located around tourist attractions that should be considered to participate in ecotourism management.

Ecotourism adheres to the conservation of natural resources and cultural resources. Planning, development, and management of all forms of tourism need to lead to sustainable development. Providing education and meaningful communication to all parties involved is essential to create awareness and concern for nature. The heart of ecotourism development is the power of the community to make decisions about self-development. Tourism should generate fair income distribution. Visitors should be satisfied with the extent that there is no destruction of resources (Phayom, T., 1998).

- Focusing on domestic tourism development first.

- Local people must participate in judging projects that will affect the way of life of most people in the area.

- Considering the ability to support tourism in every aspect.

- Focusing on using local materials and products.

- Emphasizing income distribution to local areas by focusing on long-term benefits of the community.

- Realizing the value of natural and cultural environment rather than being a tourist attraction only.

- Adaptation must not be contrary to the principles of ecotourism.

- Tourism business, local organizations, environmental organizations, and the government have a duty to work together equally (Royal Institute, 2002).

Philosophy of ecotourism (Tyler, D. and Dangerfield, J. M., 2010).

- Ecologically Sensitive means consciousness or responsibility towards the ecosystem. The responsible person is the entrepreneur, the agency responsible for the area, tourists, and people involved in the tourism industry in various parts. Therefore, the management of ecotourism must take responsibility or consciousness into the way the management is made.

- Low Impact means low impact, which is contrary to the current concept of mass tourism. Therefore, how to minimize ecotourism management? There should not be large, permanent or large facilities, but will focus on small facilities that are reasonably comfortable, harmoniously blending with nature and the environment.

- Educational means to provide information services for education to educate tourists or those who use it. For example, the tourist center in the national park, but ecotourism must have more than a service center. There should be a pedestrian path that allows people to go out and experience nature. There are documents to be used as a travel guide to study knowledge, such as animal viewing guides, bird watching, tree viewing, etc. That are related to the nature that appears in that area. 
- Local Benefit means income distribution to local people by allowing local people to participate in the management or service of tourism, ranging from accommodation systems, food, facilities, local guides, leaders, and or service providers between tourists in the area. In addition, local people must receive both direct and indirect benefits from tourism as well.

\section{METHODOLOGY}

\section{Conceptual Research Model and Hypotheses}

Conceptual research model and hypotheses are formed from the literature which is reinforced by previous studies that the author concluded is as follows:

- H1: Tourist behavior factors that affected the destination branding of ecotourism attraction in marine national park area of Krabi province.

- H2: Branding destination factors that affected the ecotourism component in marine national park area of Krabi province

Conceptual research has the purpose of showing "influence" between factors, or latent variables that have an effect on other factors, according to empirical data collected from the sample groups. Comparisons are made between previously researched conceptual models and the present structural model to see whether it is a model fit shown in figure 1

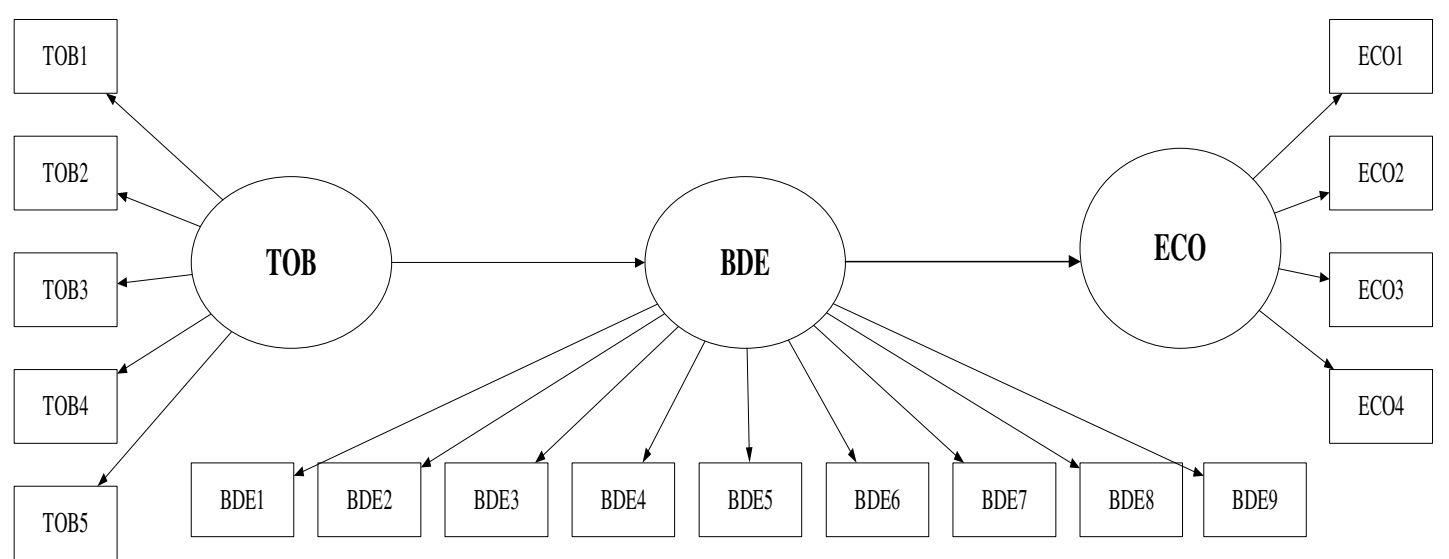

Figure 1: Conceptual Research Model.

The table showed the acronyms for testing the assertive consistency of the branding innovation model for ecotourism sites in the Krabi National Park area as follows:

Table 1: Shows an Abbreviation Description for Testing the Assertion of Conformity of the Innovative Model for Ecotourism Attraction on Branding Destination in Marine National Park area of Krabi Province.

\begin{tabular}{|l|l|c|c|}
\hline \multicolumn{1}{|c|}{ Factor } & \multicolumn{1}{|c|}{ Variables } & \multicolumn{1}{c|}{$\begin{array}{c}\text { Abbreviations used to } \\
\text { Represent Variables }\end{array}$} & $\begin{array}{c}\text { Abbreviations used in the } \\
\text { Test Results (CFA) }\end{array}$ \\
\hline \multirow{4}{*}{$\begin{array}{l}\text { 1. Ecotourism Behavior Component in Marine National Park Area of Krabi Province. } \\
\text { Behavior : } \\
\text { TOB }\end{array}$} & Tourism Behavior & TOB & XX \\
\cline { 2 - 4 } & Information perception factor & TOB1 & X1 \\
\cline { 2 - 4 } & Cultural factors & TOB2 & X3 \\
\cline { 2 - 4 } & Social factors & TOB3 & X4 \\
\cline { 2 - 4 } & Psychological factors & TOB4 & X5 \\
\cline { 2 - 4 } & Marketing factors & TOB5 & \\
\hline \multicolumn{2}{|c|}{} \\
\hline
\end{tabular}




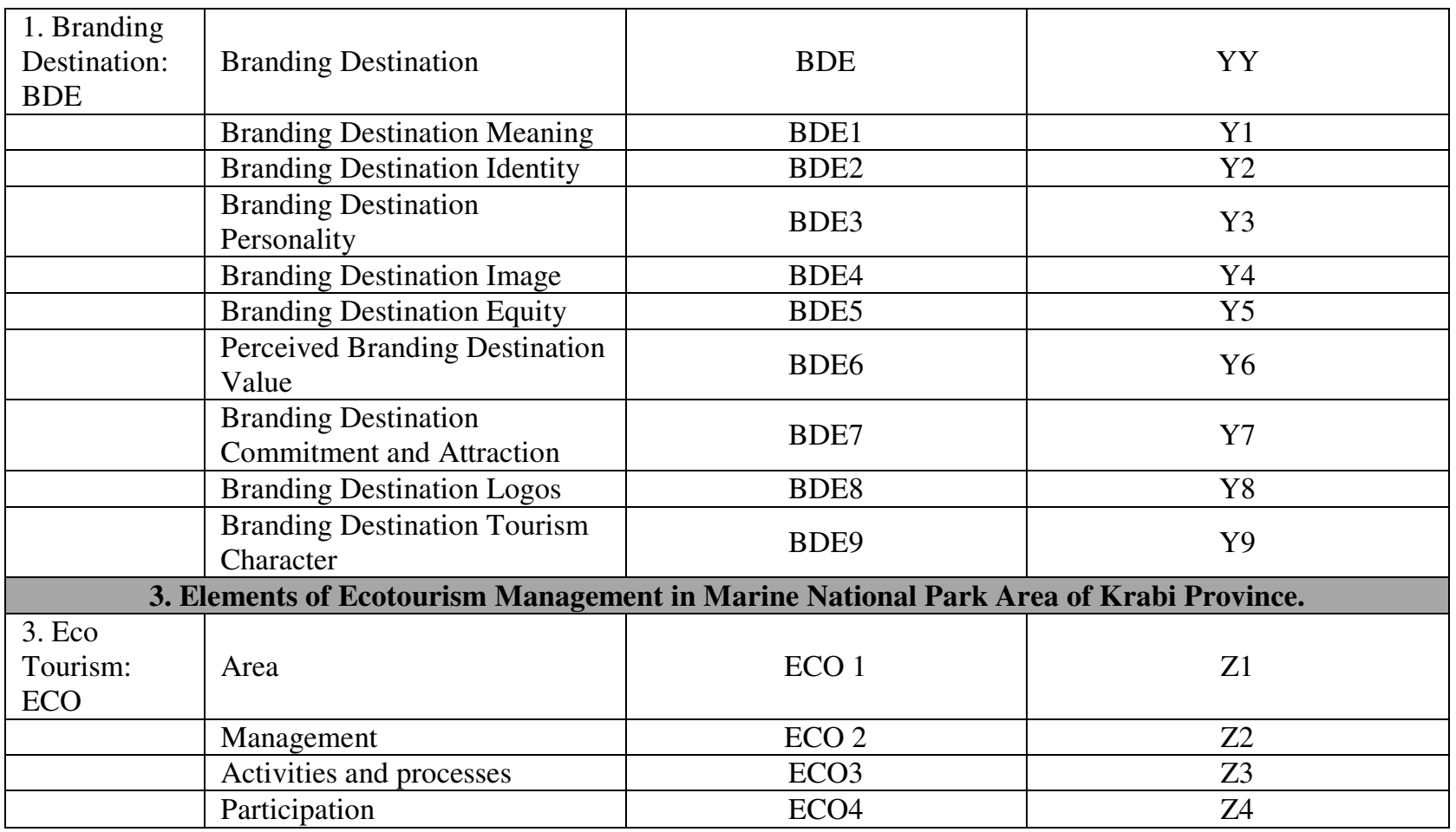

\section{Questionnaire Design and Data Collection}

A questionnaire is used for people in the local community and Thai tourists visiting the tourist attractions in the Krabi National Marine Park area. Using the questionnaires with close - ended questions and open - ended questions is for collecting quantitative data with five scoring levels based on a rating scale using Likert's method. Considering the measurement of the items in the questionnaire, were measured with a 5-level Likert scale ranging from "strongly disagree" to "strongly agree". The questionnaire was conducted group of tourists in Krabi province, Thailand, with 400 samples for analysis.

\section{Model Development}

Questionnaires will be analyzed by using descriptive statistics with frequency distribution, percentages, means, and standard deviations through the SPSS program. When the data collection is completed, the data from the questionnaire will be analyzed and calculated by using the M-PLUS program to find factor analysis. Using the exploratory factor analysis (EFA) method to define variables will group the variables that produce similar results within the same group. This variable group is called a factor. Then, analyzing the factors with confirmatory factor analysis (CFA) which measures statistical results and confirms that group analysis is categorized as a factor which can be modeled (Model Fit) perfectly or not. The final step is Structural Equation Modeling (SEM), which acts as an "influence" between factors or variables that affect the other elements in the model that relates to the innovative model of brand building, ecotourism attraction in the Krabi Marine National Park area.

\section{RESULTS AND DISCUSSIONS}

The results of Exploratory Factor Analysis (EFA)

Exploratory Factor Analysis (EFA) of Ecotourism Behavior Element in Marine

National Park Area of Krabi Province 
From entering data into the finished program, the value of Kaiser-Meyer-Olkin(KMO) was 0.932 (KMO>0.6) (Tabachnik and Fidel, 2001). The value of Bartlett's Test of Sphericity was 0.000 (Sig.). Then, checking the value of reliability of all factors had been implemented. The results of TOB1, TOB2, TOB3, TOB4, and TOB5 yielded Cronbach's Alpha were equal to $0.843,0.802,0.797,0.823$, and 0.810 , respectively. Every value was greater than 0.7 (Cronbach's $\boldsymbol{\alpha}>0.7$ ) (Nunnally, 1987). Every value was considered reliable. Analysis results as shown in Table 2

Table 2: Factor Loading of Factor Analysis According to the Topic from the Survey Factors of Ecotourism Behavior in Marine Park Area of Krabi Province.

\begin{tabular}{|c|c|c|c|c|c|c|c|c|}
\hline \multirow{2}{*}{\multicolumn{2}{|c|}{ Item }} & \multicolumn{5}{|c|}{ Component } & \multirow{2}{*}{\multicolumn{2}{|c|}{ Cronbach's $\alpha$}} \\
\hline & & \multirow{2}{*}{$\begin{array}{c}\mathbf{1} \\
.776 \\
\end{array}$} & \multirow{2}{*}{$\begin{array}{c}2 \\
.209\end{array}$} & \multirow{2}{*}{$\begin{array}{c}3 \\
.171 \\
\end{array}$} & \multirow{2}{*}{$\begin{array}{c}4 \\
.101\end{array}$} & \multirow{2}{*}{$\begin{array}{c}\mathbf{5} \\
.091\end{array}$} & & \\
\hline \multirow{4}{*}{ TOB1 } & TOB1.2 & & & & & & \multirow{4}{*}{.843} & \multirow{20}{*}{.934} \\
\hline & TOB1.4 & .757 & .215 & .059 & .221 & .116 & & \\
\hline & TOB1.1 & .736 & .257 & .162 & .336 & .103 & & \\
\hline & TOB1.3 & .696 & .145 & .181 & .143 & .133 & & \\
\hline \multirow{4}{*}{ TOB4 } & TOB 4.4 & .368 & .741 & .383 & .251 & .172 & \multirow{4}{*}{.823} & \\
\hline & TOB4.2 & .298 & .691 & .079 & .293 & .199 & & \\
\hline & TOB 4.3 & -.017 & .619 & .089 & .297 & .201 & & \\
\hline & TOB4.1 & -.151 & .557 & .103 & .216 & .287 & & \\
\hline \multirow{4}{*}{ TOB3 } & TOB3.2 & .136 & .265 & .637 & .144 & .084 & \multirow{4}{*}{.797} & \\
\hline & TOB3.1 & .361 & .491 & .637 & -.031 & -.154 & & \\
\hline & TOB3.3 & .194 & .321 & .633 & .218 & -.232 & & \\
\hline & TOB3.4 & .216 & .434 & .616 & .293 & .129 & & \\
\hline \multirow{3}{*}{ TOB5 } & TOB5.2 & .188 & .299 & .129 & .805 & .341 & \multirow{3}{*}{.810} & \\
\hline & TOB5.1 & .276 & .226 & .234 & .763 & .289 & & \\
\hline & TOB5.3 & .287 & .265 & .277 & .580 & .301 & & \\
\hline \multirow{5}{*}{ TOB2 } & TOB5.4 & .195 & .153 & .126 & .531 & .219 & \multirow{5}{*}{.802} & \\
\hline & TOB2.1 & .245 & .326 & .030 & -.056 & .781 & & \\
\hline & TOB2.2 & .256 & .145 & .255 & .121 & .706 & & \\
\hline & TOB2.3 & .406 & .065 & .339 & .288 & .659 & & \\
\hline & TOB 2.4 & .367 & .104 & .327 & .125 & .620 & & \\
\hline
\end{tabular}

According to the table 2, The analysis found that the variable that received the weight (Factor Loading) were grouped into 5 factors according to the weight value, by group factor 1 named TOB1: Information perception factor, group 2 factor named TOB2: Cultural factors, group factor 3, named TOB3: Social factors, group factor 4, named TOB4: Psychological factors, and group factors 5, named TOB5: Marketing factors, respectively.

\section{Exploratory Factor Analysis (EFA) of Branding Destination Elements for Ecotourism}

\section{Attraction in Marine National Park area of Krabi Province}

From entering data into the finished program, the value of Kaiser-Meyer-Olkin (KMO) was 0.952 (KMO>0.6) (Tabachnik and Fidel, 2001). The value of Bartlett's Test of Sphericity was 0.000 (Sig.). Then, checking the value of reliability of all factors had been implemented. The results of BDE1, BDE2, BDE3, BDE4, BDE5, BDE6, BDE7, BDE8, andBDE9 yieldedCronbach's Alpha equal to $0.847,0.845,0.839,0.847,0.851,0.842,0.883,0.849$, and 0.883 , respectively. Every value was greater than 0.7 (Cronbach's $\boldsymbol{\alpha}>0.7$ ) (Nunnally, 1987). Every value was considered reliable. Analysis results as shown in Table 4.26. Factor loading of factor analysis according to the topic from the survey factors ofecotourism behavior in the marine park area of Krabi province. 
Table 3: Factor Loading of Factor Analysis According to the Topics from the Survey Factors of Branding Destination Elements in Ecotourism Attraction of Marine National Park Area of Krabi Province.

\begin{tabular}{|c|c|c|c|c|c|c|c|c|c|c|c|c|}
\hline \multirow{2}{*}{\multicolumn{2}{|c|}{ Item }} & \multicolumn{9}{|c|}{ Component } & \multirow{2}{*}{\multicolumn{2}{|c|}{$\begin{array}{c}\text { Cronbach's } \\
\alpha\end{array}$}} \\
\hline & & 1 & 2 & 3 & 4 & 5 & 6 & 7 & 8 & 9 & & \\
\hline \multirow{5}{*}{ BDE9 } & BDE9.3 & .694 & .104 & .129 & .307 & .019 & .253 & .078 & .055 & .014 & \multirow{5}{*}{.883} & \multirow{20}{*}{.972} \\
\hline & BDE9.2 & .676 & .233 & .197 & .078 & .314 & .089 & .222 & .126 & .100 & & \\
\hline & BDE9.1 & .646 & .153 & .204 & .070 & .149 & .147 & .333 & .234 & .128 & & \\
\hline & BDE9.4 & .629 & .223 & .137 & .123 & .191 & .262 & .162 & .140 & -.029 & & \\
\hline & BDE9.5 & .619 & .241 & .220 & .117 & .390 & .030 & .159 & .112 & .107 & & \\
\hline \multirow{5}{*}{ BDE7 } & BDE7.5 & .239 & .610 & .155 & .113 & .090 & .374 & .131 & .230 & .290 & \multirow{5}{*}{.883} & \\
\hline & BDE7.3 & .249 & .593 & .253 & .277 & .202 & .006 & .129 & .056 & .003 & & \\
\hline & BDE7.4 & .326 & .570 & .211 & .379 & .246 & -.023 & -.024 & -.019 & -.002 & & \\
\hline & BDE7.1 & .226 & .569 & .252 & .478 & .131 & .041 & .036 & .081 & .096 & & \\
\hline & BDE7.2 & .201 & .553 & .175 & .464 & .227 & -.019 & .030 & .005 & .178 & & \\
\hline \multirow{5}{*}{ BDE3 } & BDE3.5 & .474 & .081 & .724 & .158 & .262 & .459 & .246 & .212 & .114 & \multirow{5}{*}{.839} & \\
\hline & BDE3.2 & .305 & .052 & .677 & .021 & .027 & .039 & .139 & .087 & .090 & & \\
\hline & BDE3.1 & .279 & .327 & .631 & .081 & .046 & .069 & .153 & .136 & .056 & & \\
\hline & BDE3.4 & .120 & .250 & .613 & .257 & .300 & .068 & .109 & .098 & .012 & & \\
\hline & BDE3.3 & .223 & .218 & .577 & .339 & .108 & .246 & .037 & .322 & .226 & & \\
\hline \multirow{5}{*}{ BDE2 } & BDE2.3 & .160 & .209 & .228 & .725 & .196 & .286 & -.033 & .143 & .076 & \multirow{5}{*}{.845} & \\
\hline & BDE2.5 & .180 & .401 & .173 & .595 & .154 & .250 & .054 & .023 & -.104 & & \\
\hline & BDE2.2 & .254 & .492 & .442 & .563 & .188 & .077 & .091 & .083 & .066 & & \\
\hline & BDE2.1 & .196 & .477 & .237 & .561 & .185 & .298 & .072 & .032 & .011 & & \\
\hline & BDE2.4 & .147 & .427 & .346 & .537 & .279 & .337 & .029 & .015 & .004 & & \\
\hline \multirow{5}{*}{ BDE5 } & BDE5.5 & .333 & .102 & .300 & .248 & .593 & .157 & .060 & .031 & .011 & \multirow{5}{*}{.851} & \\
\hline & BDE5.2 & .154 & .294 & .437 & .157 & .582 & .378 & .121 & .108 & .096 & & \\
\hline & BDE5.1 & .189 & .318 & .166 & .295 & .557 & .031 & .162 & .066 & .183 & & \\
\hline & BDE5.4 & .434 & .069 & .316 & .073 & .549 & .119 & .065 & .122 & .243 & & \\
\hline & BDE5.3 & .223 & .237 & .299 & .407 & .542 & .100 & -.201 & .235 & .154 & & \\
\hline \multirow{5}{*}{ BDE1 } & BDE1.1 & .222 & .314 & .418 & .362 & .126 & .577 & .091 & .012 & .139 & \multirow{5}{*}{.847} & \\
\hline & BDE1.2 & .171 & .316 & .313 & .224 & .207 & .561 & .227 & .101 & .078 & & \\
\hline & BDE1.5 & .053 & .342 & .490 & .174 & .274 & .551 & .178 & .221 & .070 & & \\
\hline & BDE1.4 & .172 & .213 & .224 & .079 & .429 & .539 & -.039 & .336 & .123 & & \\
\hline & BDE1.3 & .229 & .109 & .209 & .135 & .218 & .511 & .342 & .143 & .117 & & \\
\hline \multirow{3}{*}{ BDE4 } & BDE4.3 & .181 & .313 & .315 & .242 & .217 & .083 & .799 & .251 & .113 & & \\
\hline & BDE4.4 & .191 & .327 & .334 & .241 & -.137 & .256 & .682 & .231 & .315 & .847 & \\
\hline & BDE4.1 & .349 & -.006 & .137 & .211 & .056 & .219 & .676 & .114 & .101 & & \\
\hline & BDE4.2 & .132 & .376 & .348 & .516 & .040 & .190 & .580 & .201 & .189 & & \\
\hline & BDE4.5 & .199 & .278 & .227 & .499 & .316 & .164 & .536 & .073 & .051 & & \\
\hline & BDE6.5 & .382 & .123 & .217 & .176 & -.034 & .244 & -.101 & .708 & .262 & & \\
\hline BDE6 & BDE6.3 & .376 & .154 & .142 & .239 & .080 & .202 & .137 & .693 & .027 & .842 & \\
\hline & BDE6.4 & .391 & .124 & .280 & .036 & .087 & .183 & .198 & .674 & .046 & & \\
\hline & BDE6.1 & .225 & .235 & .272 & .308 & .217 & -.067 & .255 & .558 & .300 & & \\
\hline & BDE6.2 & .366 & .250 & .059 & .112 & .010 & .364 & .155 & .543 & -.019 & & \\
\hline & BDE8.3 & .119 & .260 & .473 & .212 & -.023 & .325 & .190 & .113 & .702 & & \\
\hline & BDE8.4 & .384 & .127 & .233 & .151 & .334 & .483 & .146 & .123 & .691 & & \\
\hline & BDE8.1 & .353 & .149 & .111 & .216 & .121 & .136 & .437 & .178 & .652 & & \\
\hline & BDE8.5 & .209 & .152 & .112 & .159 & .501 & .161 & .257 & .197 & .619 & & \\
\hline BDE8 & BDE8.2 & .454 & .282 & .274 & .146 & .042 & .152 & .142 & .109 & .577 & .849 & \\
\hline & BDE8.4 & .384 & .127 & .233 & .151 & .334 & .483 & .146 & .123 & .691 & & \\
\hline & BDE8.1 & .353 & .149 & .111 & .216 & .121 & .136 & .437 & .178 & .652 & & \\
\hline & BDE8.5 & .209 & .152 & .112 & .159 & .501 & .161 & .257 & .197 & .619 & & \\
\hline & BDE8.2 & .454 & .282 & .274 & .146 & .042 & .152 & .142 & .109 & .577 & & \\
\hline
\end{tabular}

From table 3 the results of the analysis showed that variables that received various weight factors were grouped into 9 factors based on weight values. That was, Group 1 was BDE1 (Branding Destination Meaning). Group 2 was BDE2 
(Branding Destination Identity). Group 3 was BDE3 (Branding Destination Personality). Group 4 was BDE4 (Branding Destination Image). Group 5 was BDE5 (Branding Destination Equity).Group 6 was BDE6 (Perceived Branding Destination Value). Group 7 was BDE7 (Branding Destination Commitment and Attractant). Group 8 wasBDE8 (Branding Destination Logos), and Group 9 was BDE9 (Branding Destination Tourism Character), respectively.

The Results of Confirmatory Factor Analysis (CFA) of Innovative Model for Ecotourism

Attraction on Branding Destination in Marine National Park Area of Krabi Province

The data analysis in this section was the result of the consistency testing of the innovative model for ecotourism attraction on branding destination in marine national park area of Krabi province with empirical data by confirmatory component analysis. After amendments, the model was completely fit with $\mathrm{X} 2=117.025, \mathrm{Df}=97, \mathrm{X} 2 / \mathrm{Df}=1.2064$, P-Value $=$ $0.0813, \mathrm{RMSEA}=0.023, \mathrm{SRMR}=0.021, \mathrm{CFI}=0.997, \mathrm{TLI}=0.995$. The results of the analysis were as follows figure 2

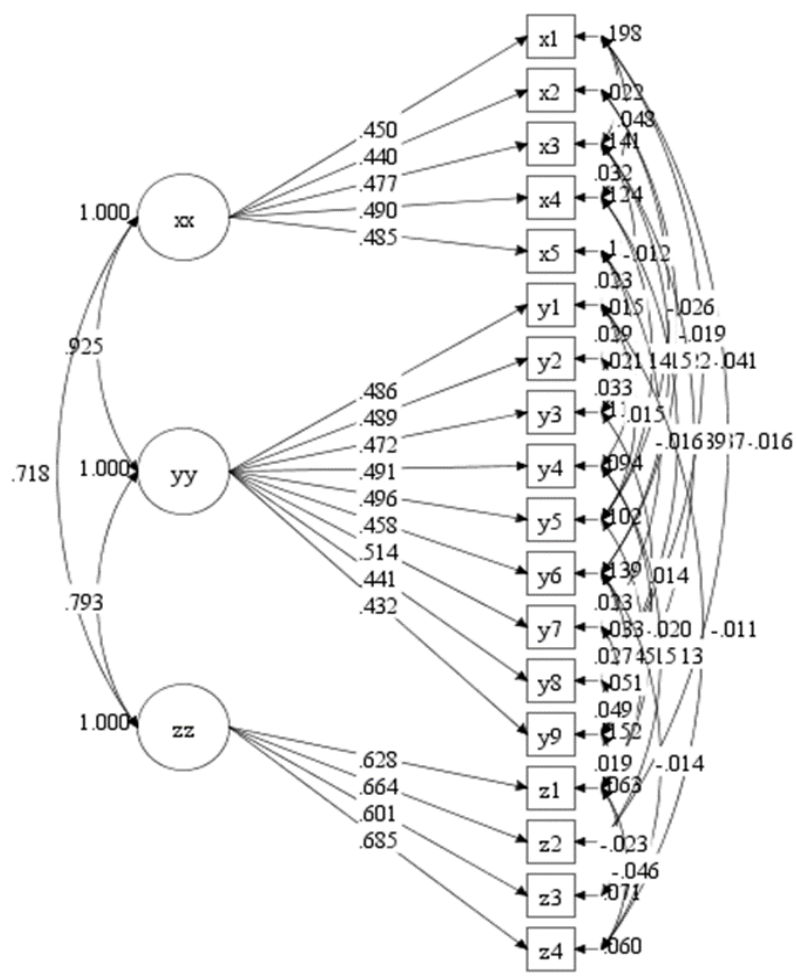

Figure 2: The First Factor Confirmatory Factor Analysis of the Innovative Model for Ecotourism Attraction on Branding Destination in Marine National Park Area of Krabi Province.

Table 4: Shows the Goodness of Fit Index (GFI) of the Innovative Model for Ecotourism Attraction on Branding Destination in Marine National Park Area of Krabi Province

\begin{tabular}{|c|c|c|c|}
\hline Goodness of fit Index (GFI) & Criteria & Analysis Results & Result \\
\hline $\mathrm{X}^{2}-$ Test & $\begin{array}{c}\text { Insignificant } \\
\mathrm{P}>0.05\end{array}$ & $\begin{array}{c}\mathrm{X}^{2}=117.025 \\
\mathrm{Df}=97, \\
\mathrm{P}-\mathrm{Value}=0.0813\end{array}$ & Passed \\
\hline $\mathrm{X}^{2} / \mathrm{Df}$ & $<2.00$ & 1.2064 & Passed \\
\hline RMSEA & $\leq 0.05$ & 0.023 & Passed \\
\hline SRMR & $\leq 0.08$ & 0.021 & Passed \\
\hline CFI & $\geq 0.95$ & 0.997 & Passed \\
\hline TLI & $\geq 0.95$ & 0.995 & Passed \\
\hline
\end{tabular}


From table 4, it was found that the Goodness of fit index (GFI) of the innovative model for ecotourism attraction on branding destination in marine national park area of Krabi province was in accordance with the criteria. When considering the Chi-squaredvalue equal to 117.025, the degree of freedom (Df) was equal to 97, and the statistical significance (P-Value) was 0.0813, indicating that the Chi-squared value was not statistically significant. The Root Mean Square Error of Approximation (RMSEA) equal to 0.023, Standardized Root Mean Square Residual (SRMR) was 0.021, Comparative Fit Index (CFI) equal to 0.997, and Tucker-Lewis Index (TLI) was equal to 0.995 showing that the model fits with empirical data.

\section{Structure Equation Model (SEM) for Adjusting the Innovative Model for Ecotourism Attraction on Branding Destination in Marine National Park Area of Krabi Province}

Adjusting the innovative model for ecotourism attraction on branding destination in marine national park area of Krabi province. The researcher had adjusted the model according to the Modification Indies which had the highest value until the model had a goodness of fit. The Goodness of fit index of the innovative model for ecotourism attraction on branding destination in marine national park area of Krabi province was based on the following criteria; The Chi-squared value was 118.567. The degree of freedom (Df) was equal to 98. The statistical significance (P-Value) was equal to 0.077 . These mean that the Chi-squared had no statistical significance.The Root Mean Square Error of Approximation was 0.023. Standardized Root Mean Square Residual (SRMR) was 0.021. Comparative fit index (CFI) equal to 0.997. Tucker-Lewis Index (TLI) was 0.995. After amendments, the model was completely fit with X2 = 118.567, Df $=98, \mathrm{X} 2 / \mathrm{Df}=1.2098$, PValue $=0.0772$, RMSEA $=0.023$, SRMR $=0.021, \mathrm{CFI}=0.997, \mathrm{TLI}=0.995$. These showed that the model fits with empirical data according to the image.



Figure 3: Structural Model of the Innovative Model for Ecotourism Attraction on Branding Destination in Marine National Park Area of Krabi Province. 
Table 5: Shows the Goodness of Fit Index of the Innovative Model for Ecotourism Attraction on Branding Destination in Marine National Park Area of Krabi Province.

\begin{tabular}{|c|c|c|c|}
\hline Goodness of fit index (GFI) & Criteria & Analysis results & Result \\
\hline$X^{2}-$ Test & $\begin{array}{c}\text { Insignificant } \\
\text { P }>0.05\end{array}$ & $\begin{array}{c}X^{2}=118.567 \\
\text { Df }=98, \\
\text { P-Value }=0.077\end{array}$ & Passed \\
\hline$X^{2}$ Df & $<2.00$ & 1.209 & Passed \\
\hline RMSEA & $\leq 0.05$ & 0.023 & Passed \\
\hline SRMR & $\leq 0.08$ & 0.021 & Passed \\
\hline CFI & $\geq 0.95$ & 0.997 & Passed \\
\hline TLI & $\geq 0.95$ & 0.995 & Passed \\
\hline
\end{tabular}

From table 5, it was found that the Goodness of fit index (GFI) of the innovative model for ecotourism attraction on branding destination in marine national park area of Krabi province was in accordance with the criteria. When considering the Chi-squaredvalue equal to 118.567, the degree of freedom (Df) was equal to 98, and the statistical significance (P-Value) was 0.077, indicating that the Chi-squared value was not statistically significant. The Root Mean Square Error of Approximation (RMSEA) was equal to 0.023, Standardized Root Mean Square Residual (SRMR) was 0.021, Comparative fit index (CFI) equal to 0.997, and Tucker-Lewis Index (TLI) was equal to 0.995 show that the model fits with empirical data.

The Results of the Analysis of the Main Components and Sub-Elements of the Innovative Model for Ecotourism Attraction on Branding Destination in Marine National Park Area of Krabi Province.

As a result of studying the innovative model for ecotourism attraction on branding destination in marine national park area of Krabi province, the researcher would present the results as follows:

\section{Confirmed Component Analysis Results of Factors Affecting Ecotourism Behavior} in Marine National Park Area of Krabi Province.

Table 6: Shows the Results of Confirmatory Component Analysis in Terms of Factors that Affect Ecotourism Behavior in Marine National Park Area of Krabi Province.

\begin{tabular}{|c|c|c|c|c|c|}
\hline \multirow{2}{*}{ Variable } & \multirow{2}{*}{ Components } & \multicolumn{3}{|c|}{ Element weight } & \multirow{2}{*}{ Coefficient $\left(\mathbf{R}^{2}\right)$} \\
\hline & & $\beta$ & S.E. & $\mathbf{t}$ & \\
\hline \multirow{5}{*}{$\begin{array}{l}\text { Factors affecting ecotourism } \\
\text { behavior } \\
\text { (TOB) }\end{array}$} & Information perception $\left(\mathrm{TOB}_{1}\right)$ & 0.482 & 0.029 & 16.833 & 0.580 \\
\hline & Cultural aspects $\left(\mathrm{TOB}_{2}\right)$ & 0.443 & 0.027 & 16.197 & 0.526 \\
\hline & Social aspects $\left(\mathrm{TOB}_{3}\right)$ & 0.483 & 0.026 & 18.657 & 0.634 \\
\hline & Psychology aspects $\left(\mathrm{TOB}_{4}\right)$ & 0.496 & 0.026 & 19.324 & 0.676 \\
\hline & Marketing aspects $\left(\mathrm{TOB}_{5}\right)$ & 0.484 & 0.025 & 18.977 & 0.653 \\
\hline
\end{tabular}

From table 6, factors that affected ecotourism behavior (TOB) found that in the overall picture, each factor had the element weight (Factor Loading) from $0.443-0.496$. The composition in the standard score with the highest component weight was the psychological factor (TOB4) which had the element weight (Factor Loading) equal to 0.496 and the coefficient $\left(\mathrm{R}^{2}\right)$ equal to 0.676 , followed by the marketing factor (TOB5) which had the element weight (Factor Loading) equal to 0.484 and the coefficient $\left(\mathrm{R}^{2}\right)$ equal to 0.653 . The composition in the standard score with the least element weight was the cultural factor (TOB2) which had the element weight (Factor Loading) equal to 0.443 andcoefficient ( $\mathrm{R}^{2}$ ) equal to 0.526. When considering the composition of the weight in the standard score of each component, factors affecting the ecotourism behavior could be sorted according to the composition of the weight from descending as follows: psychological factors, marketing factors, social factors, perceiving information factors, and cultural factors, respectively. 


\section{Confirmed Component Analysis Results of Factors Affecting Ecotourism Behavior in}

\section{Marine National Park Area of Krabi Province}

Table 7: Shows the Results of Confirmatory Component Analysis of Branding Destination of Ecotourism Attraction in the Marine National Park Area of Krabi Province

\begin{tabular}{|c|c|c|c|c|c|}
\hline \multirow{2}{*}{ Variables } & \multirow{2}{*}{ Components } & \multicolumn{3}{|c|}{ Element Weight } & \multirow{2}{*}{$\begin{array}{c}\text { Coefficient } \\
\left(\mathbf{R}^{2}\right)\end{array}$} \\
\hline & & $\beta$ & S.E. & $\mathbf{t}$ & \\
\hline \multirow{9}{*}{$\begin{array}{l}\text { Branding } \\
\text { destination } \\
\text { (BDE) }\end{array}$} & Brand destination meaning $\left(\mathrm{BDE}_{1}\right)$ & 0.487 & 0.024 & 20.216 & 0.595 \\
\hline & Branding destination identity $\left(\mathrm{BDE}_{2}\right)$ & 0.489 & 0.024 & 20.386 & 0.701 \\
\hline & Branding destination personality $\left(\mathrm{BDE}_{3}\right)$ & 0.471 & 0.024 & 19.286 & 0.652 \\
\hline & Branding destination image $\left(\mathrm{BEB}_{4}\right)$ & 0.492 & 0.024 & 20.902 & 0.721 \\
\hline & Branding destination equity $\left(\mathrm{BEB}_{5}\right)$ & 0.499 & 0.024 & 20.638 & 0.713 \\
\hline & Perceive Branding destination value $\left(\mathrm{BEB}_{6}\right)$ & 0.460 & 0.025 & 18.221 & 0.606 \\
\hline & $\begin{array}{l}\text { Branding destination commitment and attraction } \\
\left(\mathrm{BED}_{7}\right)\end{array}$ & 0.514 & 0.025 & 20.269 & 0.698 \\
\hline & Branding destination logo $\left(\mathrm{BDE}_{8}\right)$ & 0.440 & 0.024 & 18.153 & 0.605 \\
\hline & Branding destination tourism character $\left(\mathrm{BDE}_{9}\right)$ & 0.433 & 0.025 & 17.135 & 0.556 \\
\hline
\end{tabular}

From table 7, the branding destination component of ecotourism attraction (BDE) found that the overall composition of each component had a weight component (Factor Loading) from $0.433-0.514$. The composition in the standard score with the highest component weight was the branding destination commitment and attraction (BDE7), which had the element weight (Factor Loading) equal to 0.514 and with the coefficient $\left(\mathrm{R}^{2}\right)$ equal to 0.698 , followed by the Branding destination equity (DEB5) which had the element weight (Factor Loading) equal to 0.499 and with coefficient $\left(\mathrm{R}^{2}\right)$ equal to 0.713 . The composition in the standard score with the least element weight was the role of Branding destination tourism character (DEB9), which had the factor load (0.433) and the coefficient $\left(\mathrm{R}^{2}\right)$ equal to 0.556 .

In addition, when considering the weight composition in the form of standard scores of each component of branding destination for ecotourism attraction, the order could be sorted according to the weight of elements from descending order as follows: 1. Brand destination meaning, 2. Branding destination identity, 3. Branding destination personality, 4. Branding destination image, 5. Branding destination equity, 6. Perceive Branding destination value, 7. Branding destination commitment and attraction, 8. Branding destination logo, and Branding destination tourism character respectively.

\section{Confirmed Component Analysis Results in Terms of Ecotourism Attraction Management in}

Marine National Park Area of Krabi Province

Table 8: Shows the Results of the Confirmatory Component Analysis of Ecotourism Attraction Management in Marine National Park Area of Krabi Province

\begin{tabular}{|l|l|c|c|c|c|}
\hline \multirow{2}{*}{ Variables } & \multicolumn{1}{|c|}{ Components } & \multicolumn{3}{c|}{ Element Weight } & \multirow{2}{*}{ Coefficient $\left(\mathbf{R}^{\mathbf{2}}\right)$} \\
\cline { 2 - 5 } & & $\beta$ & S.E. & $\mathbf{t}$ & \\
\hline \multirow{2}{*}{$\begin{array}{l}\text { Ecotourism } \\
\text { management } \\
(\text { ECO) }\end{array}$} & Area (ECO1) & 0.628 & 0.027 & 23.693 & 0.862 \\
\cline { 2 - 5 } & Management (ECO2) & 0.662 & 0.028 & 23.309 & 0.818 \\
\cline { 2 - 5 } & Activities and processes (ECO3) & 0.601 & 0.025 & 23.627 & 0.836 \\
\cline { 2 - 5 } & Participation (ECO4) & 0.684 & 0.028 & 24.869 & 0.886 \\
\hline
\end{tabular}

From table 8, Ecotourism Management (ECO) found that the overall picture of each factor had a weight component (Factor Loading) from 0.601 - 0.684.The composition in the standard score with the highest component weight was the participation (ECO4) which had the element weight (Factor Loading) equal to 0.684 and coefficient $\left(\mathrm{R}^{2}\right)$ equal to 0.886, followed by management (ECO2) which had the element weight (Factor Loading) equal to 0.662 and coefficient 
$\left(\mathrm{R}^{2}\right)$ equal to 0.818 . The composition in the standard score with the lowest component weight was activity and process (ECO3) which had the element weight (Factor Loading) equal to 0.601 and coefficient $\left(\mathrm{R}^{2}\right)$ equal to 0.836 . In addition, when considering the composition of the weight in the form of a standard score of each element of ecotourism management, it could be sorted according to the element's weight in descending order as follows: participation, management, area, and activities as well as processes, respectively.

\section{Results of Hypothesis Testing of the Innovative Model for Ecotourism Attraction on}

\section{Destination Branding in Marine National Park Area of Krabi Province}

Table 9: Shows the Analysis of the Confirmed Element Hypothesis of the Innovative Model for Ecotourism Attraction on Branding Destination in Marine National Park Area of Krabi Province

\begin{tabular}{|l|c|c|c|c|}
\hline \multicolumn{1}{|c|}{ Variables } & \multicolumn{2}{|c|}{ Element weight } & \multirow{2}{*}{ Result } \\
\cline { 2 - 4 } & $\square$ & S.E. & t & \\
\hline $\begin{array}{l}\text { Tourist behavior factors that affected the destination branding of ecotourism } \\
\text { attraction in marine national park area of Krabi province }\end{array}$ & 0.901 & 0.016 & 57.667 & supported \\
\hline $\begin{array}{l}\text { Branding destination factors that affected the ecotourism component in } \\
\text { marine national park area of Krabi province }\end{array}$ & 0.791 & 0.021 & 37.298 & supported \\
\hline
\end{tabular}

From table 9, the results of the analysis of the confirmed component hypothesis of the innovative model for ecotourism attraction on destination branding in marine national park area of Krabi province were as follows:

- Tourist behavior factors that affected the branding destination of ecotourism attraction in marine national park area of Krabi province had factor loading equal to 0.901 or 90.10 percent. It could be said that tourist behavior factors affecting the branding destination of ecotourism attraction in marine national park area of Krabi province were $90.10 \%$.

- Branding destination factors that affected the ecotourism component in marine national park area of Krabi province had factor loading of 0.791 or 79.10 percent. It could be said that creating a branding destination of ecotourism attractions that affects the ecotourism management component in marine national park area of Krabi province was 79.10 percent.



Figure 4: Shows the Results of the Analysis of the Confirmed Element Hypothesis of the Innovative Model for Ecotourism Attraction on Branding Destination in Marine National Park Area of Krabi Province.

\section{CONCLUSIONS}

This research presented the innovative model for ecotourism attraction on destination branding in marine national park area of Krabi province. 400 samples of tourists, were selected to confirm the model. The model was developed by the statistical techniques, including the EFA, CFA, Structural model, and modified structural model. a final structural model according to the tourist opinions from Krabi Province, Thailand, as element of tourism behavior in marine national park area of Krabi province consisted of the following 5 factors: 1) Information perception factor. 2) Cultural factors. 3) Social factors 4) Psychological factors and 5) Marketing factors. Elements of branding destination of marine national park area of Krabi province. consisted of the following 9 factors: 1) Branding Destination Meaning 2) Branding Destination Identity 3) 
Branding Destination Personality 4) Branding Destination Image 5) Branding Destination Equity 6) Perceive Branding

Destination Value 7) Branding Destination Commitment and Attraction 8) Branding Destination Logos and 9) Branding Destination Tourism Character. Elements of ecotourism management of marine national park area of Krabi province consisted of the following 4 factors: 1) Area 2) Management 3) Activities and processes and 4) Participation.

\section{ACKNOWLEDGMENTS}

This research was supported by National Research Council of Thailand (NRCT): Research Scholarship for Graduate Students of 2018, and this article is part of a thesis titled "The Innovative Model for Ecotourism Attraction on Branding Destination in Marine National Park Area of KrabiProvince, Doctor of Philosophy Program in Tourism and Hospitality Innovation Management, Faculty of Business Administration and Accountancy, KhonKaen University, Thailand.

\section{REFERENCES}

1. Aaker, David A. (1997). Managing Brand Equity: Capitalizing on the value of a brand name.New York: The Free Press.

2. Aaker, David A. and Joachimsthaler E. (2000). The Brand Relationship Spectrum: The Key to the Brand Architecture Challenge. California Management Review. 42(4), 8-23.

3. Alhemoud, A.M. and Armstrong, E.G. (1996).Image of tourism attractions in Kuwait.Journal of Travel Research, 34(4), 76-80.

4. Arnould, Eric, Linda Price, and George M. Zinkhan. (2002). Consumers. Boston: McGraw Hill.

5. Apisit, C. and Lakkhana, L. (2005). Creating a brand image, strategic tools to victory in the current marketing war.Journal of Business Administration, 28(105), 55-72.

6. Azoulay\&Kapferer. (2003). Do brand personality scales really measure brand personality? Journal of Brand Management. 11(2), 143-155.

7. Beerli and Martiin.(2004). Factors influencing destination image.Annals of Tourism Research. 31(3), 657-681.

8. Blain, C., Levy, S., and Ritchie, J. (2005). Destination Branding: Insights and Practices from Destination Management Organizations. Journal of Travel Research, 43(4), 328-338.

9. Botterill. (1987). The Rationality of Induction. Analytic Philosophy. 28(3), 189-192.

10. Bui, T.L.H., Perez, G.S.A. (2010), Destination Branding: The Comparative Case Study of Guam and Vietnam. Journal of International Business Research.9, (2),95-110.

11. Cohen, E. (1979). A Phenomenology of Tourist Experience.Sociology.13,(1), 179-201.

12. Cohen,L., and Manion,L. (1989). Research Method in Education. 3rd.Ed. London: Routledge.

13. Dos Reis $\square$ Neto, Armando Soares, Antonio Jeovah DE Andrade Meireles, and M. Cunha $\square$ Lignon. "Analyses of the mangrove's rehabilitation process in abandoned saltwork area, in the Cearáriver, Northeast Brazil." International Journal of Applied and Natural Sciences 2.5 (2013): 27-36.

14. Echtner, C., and Ritchie, B. (2003). The Measurement of Destination Image: an empirical assessment. Journal of Travel Research, 31(4), 3-13.

15. Ekinci and Hosany. (2006). Destination Personality: An Application of Brand Personality to Tourism Destinations. Journal of Travel Research. 45(2), 127-139. 
16. Grandey et al. (2005). Is "service with a smile" enough? Authenticity of positive displays during service encounters. Organizational Behavior and Human Decision Processes. 96(1), 38-55.

17. Sharma, N. E. E. R. A. J., Y. P. Mathur, and A. S. Jethoo."Effects of hydrological changes on the biodiversity at Keoladeo National Park and their impact on Ecotourism." International Journal of Civil, Structural, Environmental and Infrastructure Engineering Research and Development (IJCSEIERD) Vol, 5 (6), 110 (2015).

18. Sindhu, Devender, and Dalbir Singh."Ecotourism and Local Perception about its Impacts a Study of Village Sam, Jaisalmer, Rajasthan." International Journal of Environment, Ecology, Family and Urban Studies (IJEEFUS) 4.6 (2014): 1-6.

19. Shukla, Pawan K., and A. A. Ansari."A Study of Changing Scenario of Tourism Development in Gujarat." International Journal of Environment, Ecology, Family and Urban Studies 3.2 (2013): 57-68.

20. Helen Perkins,.H. and Debra Ann Grace, A. D. (2009). Ecotourism: Supply of nature or tourist demand? Journal of Ecotourism. 8(3), 1-31.

21. Hultman, et al. (2015).Achieving tourist loyalty through destination personality, satisfaction, and identification.Journal of Business Research. 68(11), 2227-2231.

22. Jirasek, T. and Apisit, C. (2007).Brand Image Building. Bangkok: Hospital Pharmacy Association of Thailand.

23. Kanungphon, W. et al. (2012).Strategy Development of Sustainable Ecotourism on Samed Island, Rayong Province.Journal of Thai Hospitality \& Tourism, 7(2), 86-103.

24. Kapferer, J. N. (2008). The New Strategic Brand Management: Creating and sustaining brand equity long term 4th Edition. British Library Cataloguing in Publication data.

25. Kim and Lehto. (2013). Projected and Perceived Destination Brand Personalities The Case of South Korea. Journal of Travel Research.52(1), 117-130.

26. Kim, W. H. et al. (2018). Destination Personality, Destination Image, and Intent to Recommend: The Role of Gender, Age, Cultural Background, and Prior Experiences. Sustainability. 10(87), 1-18.

27. Kotler, P., \& Keller, K. L. (2012).Marketing management (14th ed.). New Jersey: Pearson Prentice Hall.

28. Kotler, P., \& Armstrong, G. (2014).Principle of marketing (15th ed.). New Jersey: Pearson Prentice Hall.

29. Lidia Andrades, L., Dimanche, F. and Ilkevich, S. (2015).Tourist Behaviour and Trends.Tourism in Russia: A Management Handbook, Chapter 4. Publisher: Emerald.

30. Maja Konecnik. R. and Leslie De C. (2013). Developing and applying a place brand identity model: The case of Slovenia. Journal of Business Research. 66(1), 45-52.

31. National Tourism Policy Committee. (2017). National Tourism Development Plan No. 12, 2017 - 2021. Bangkok: Ministry.

32. Office of the National Economic and Social Development Board. (2017). The National Economic and Social Development Plan The Twelfth Plan (2017 - $\quad$ 2021).Retrieved $17 \quad$ June 2017, from http://www.nesdb.go.th/nesdb_en/main.php?filename=develop_issue. (in Thai).

33. Olimpia.B. (2008). Variables of The Image of tourist Destination.Annals of Faculty of Economics. 2(1), 554-559.

34. Otto and Ritchie. (1996). The service experience in tourism. Tourism Management. 17(3),165-174.

35. Pradit, C. (2004). Branding and marketing communication. Bangkok:Pack Inter Group Company Limited. 
36. Reynolds, T. J., \&Gutman, J. (1988).Laddering theory, method, analysis, and interpretation.Journal of Advertising Research, 28(1), 11-31.

37. Russell. (2003). Affect and the Psychological Construction of Emotion.Psychological Review.110(1), 145-72.

38. Schwartz, H. S. Are There Universal Aspects in the Structure and Contents of Human Values? Journal of Social Issues. 50(4), $19-45$.

39. Swarbrooke, J. and Horner, S. (2007). Consumer Behavior in Tourism, 2nd edition, Butterworth-Heinemann, Oxford.

40. Thaler, R. (1985).Mental Accounting and Consumer Choice.Marketing Science. 4(3), 199-214.

41. Tyler, D. and Dangerfield, J. M. (2010). Ecosystem Tourism: A Resource-based Philosophy for Ecotourism. Journal of Sustainable Tourism. 7(2), 146-158.

42. Upendra, K. M,. (2012). What is a brand? A Perspective on Brand Meaning.European Journal of Business and Management. 4(3), 122-133.

43. William D. Perreault,Donna K. Darden \&William R. Darden. (2018). A Psychological Classification of Vacation Lifestyles.Journal of Leisure Research, 9(3), 208-224. 